\title{
Listerioza - rzadka choroba o poważnym rokowaniu
}

\section{Listeriosis - a rare disease with a serious prognosis}

\author{
Agata Jankowska ${ }^{凶}$, Anna Borowiak, Agnieszka Kordek, Beata Łoniewska
}

Samodzielny Publiczny Szpital Kliniczny nr 2 Pomorskiego Uniwersytetu Medycznego w Szczecinie, Klinika Patologii Noworodka, ul. Unii Lubelskiej 1, 71-252 Szczecin Independent Public Clinical Hospital No. 2 of the Pomeranian Medical University in Szczecin, Department of Neonatal Diseases

$\triangle$ agatajankowska@hotmail.com

\begin{abstract}
Listeriosis is an infection caused by Gram-positive bacteria mostly present in food of animal origin consumed cold. The infection occurs most commonly via the oral route. The disease usually affects immunodeficient patients, pregnant women and newborns. In neonates it can appear as an early or late onset
\end{abstract}

infection depending on the time of becoming infected, the course being very grave and mortality very high, with neurological complications appearing in $10-15 \%$ of cases. In this case study the authors present a case a newborn with a severe maternal infection of Listeria monocytogenes.

Keywords: listeriosis; newborn; infection.

\begin{abstract}
ABSTRAKT
Listerioza jest chorobą zakaźną wywołaną przez Gram-dodatnią bakterię występującą przede wszystkim w produktach spożywczych pochodzenia zwierzęcego spożywanych na zimno. Do zakażenia dochodzi najczęściej drogą pokarmową. Choroba dotyka głównie osób z obniżoną odpornością, kobiet ciężarnych i noworodków, u których może występować w postaci wczesnej
\end{abstract}

lub późnej, w zależności od czasu, w jakim doszło do zakażenia. Przebieg choroby jest bardzo ciężki, śmiertelność bardzo wysoka, a powikłania neurologiczne występują u 10-15\% dzieci. W pracy przedstawiono przypadek noworodka z wrodzonym zakażeniem Listeria monocytogenes.

Słowa kluczowe: listerioza; noworodek; zakażenie.

\section{WSTĘP}

Listeria monocytogenes to Gram-dodatnia bakteria należąca do rodziny Corynobacteriacae. Ta mała, ruchliwa pałeczka dość powszechnie występuje w środowisku naturalnym - w glebie, gnijących roślinach, ściekach, odchodach ludzkich i zwierzęcych. Odporność na warunki środowiskowe oraz zdolność do wzrostu w szerokim zakresie temperatur $\left(3-45^{\circ} \mathrm{C}\right)$ sprawia, iż niektóre produkty spożywcze, szczególnie te przechowywane w lodówce (wyroby garmażeryjne, surowe mleko, sery dojrzewające, mięso i jego przetwory, sałatki z dodatkiem surowych warzyw), są często zanieczyszczone pałeczkami listerii. Bakteria ta jest odporna na ogrzewanie do $60^{\circ} \mathrm{C}$ oraz wysokie stężenie $\mathrm{NaCl}$, dlatego też typowa obróbka pokarmów jej nie niszczy $[1,2,3,4,5,6]$.

Listeria monocytogenes jest patogenem wewnątrzkomórkowym zdolnym do wnikania, namnażania się i rozprzestrzeniania w komórkach nabłonka jelitowego, śródbłonka naczyń czy trofoblastu. Do zakażenia dochodzi najczęściej na drodze pokarmowej. Szacuje się, że nosicielami jest ok. $5 \%$ populacji. U dorosłych zakażenie najczęściej przebiega bezobjawowo lub skąpoobjawowo i ma charakter samoograniczający się, jednak w grupie osób zwiększonego ryzyka (osoby starsze, osoby z obniżoną odpornością, kobiety w ciąży oraz noworodki) może przybrać postać zakażenia inwazyjnego [3, 4, 5, 7, 8].
Listerioza u kobiet ciężarnych występuje 18-krotnie częściej niż w pozostałej części populacji. Zakażenie może być przyczyną poronienia, obumarcia płodu, porodu przedwczesnego, sepsy, zapalenia płuc, niewydolności oddechowej lub zapalenia opon mózgowo-rdzeniowych u noworodków [3, 9]. Do zainfekowania L. monocytogenes noworodka może dochodzić przez łożysko, poprzez aspirację zakażonego płynu owodniowego lub z powodu zakażenia wstępującego z pochwy (zakażenia prenatalne) oraz w trakcie porodu podczas przechodzenia noworodka przez kanał rodny, gdy pochwa jest skolonizowana przez pałeczki L. monocytogenes (zakażenia perinatalne) $[1,3,4,5]$.

Częstość występowania listeriozy w okresie noworodkowym szacowana jest na 8,6/100 000 żywych urodzeń. Choroba ta zazwyczaj cechuje się ostrym przebiegiem oraz wysokim odsetkiem przypadków śmiertelnych (20-60\%) [5, 9]. Zakażenie może przebiegać jako postać wczesna (early-onset infection) - do 5. doby życia (d.ż.) lub postać późna (late-onset infection) - powyżej 5. d.ż. [1, 2, 4, 5, 6, 10].

W postaci wczesnej, zwanej także wrodzoną, objawy pojawiają się zwykle po kilku godzinach po urodzeniu lub w ciągu kilku pierwszych dni życia, a stan kliniczny noworodka jest bardzo ciężki. U dziecka stwierdza się sepsę (8188\%), zapalenie płuc (38\%), niewydolność krążeniowo-oddechową, powiększenie wątroby i śledziony oraz zapalenie opon mózgowo-rdzeniowych (24\%). Śmiertelność wynosi ok. 50\%. 
Patognomicznym objawem ciężkiego zakażenia u noworodka jest ziarniniakowatość (granulomatosis infantiseptica), która charakteryzuje się obecnością rozsianych mikroropni oraz tworzeniem ziarniniaków na skórze, w wątrobie, nadnerczach, śledzionie i płucach [8]. Niekiedy stwierdza się także występowanie wysypki skórnej o charakterze grudkowo-krostkowym. We wstępnym rozpoznaniu listeriozy u noworodka oprócz objawów klinicznych należy zwrócić uwagę również na wyniki badań laboratoryjnych, które wskazują na obecność stanu zapalnego (leukocytoza, podwyższone stężenie białka C-reaktywnego - CRP) [1, 8]. Podstawowym badaniem potwierdzającym rozpoznanie jest dodatni posiew krwi lub płynu mózgowo-rdzeniowego [6].

Postać późna jest wynikiem zakażenia okołoporodowego, do którego dochodzi poprzez aspirację płynu owodniowego lub po ekspozycji na patogen w kanale rodnym. Zazwyczaj stwierdza się sepsę (17-95\%) oraz zapalenie opon mózgowo-rdzeniowych (67-93\%) albo zapalenie mózgu, a śmiertelność w tej postaci wynosi ok. 10\%. Objawy zazwyczaj pojawiają się w 2. lub 3. tyg. życia. U dzieci po przebytym zakażeniu mogą występować ciężkie powikłania neurologiczne, w tym opóźnienie rozwoju umysłowego. Chociaż istnieją skuteczne metody terapii, pełne wyleczenie uzyskuje się u ok. 60-80\% noworodków [6]. Listeria bytuje wewnątrzkomórkowo, dlatego w leczeniu stosuje się leki penetrujące do wnętrza komórki i utrzymujące tam wysokie stężenie terapeutyczne. Spośród leków rekomendowanych należy wymienić antybiotyki beta-laktamowe w monoterapii lub w skojarzeniu z aminoglikozydem. Cefalosporyny nie są stosowane ze względu na naturalną odporność listerii na tę grupę antybiotyków $[1,5,10]$.

\section{OPIS PRZYPADKU}

Przedstawiono przypadek noworodka płci męskiej z ciąży II, porodu II, urodzonego w 31. tyg. ciąży cięciem cesarskim ze wskazań: poród w toku, zagrożenie płodu. Wywiad okołoporodowy był obciążony cukrzycą ciężarnych typu 1, nadczynnością tarczycy oraz epizodem biegunki ze stanem podgorączkowym na tydzień przed rozwiązaniem ciąży. Wody płodowe były zielone. Chłopiec urodził się w stanie ogólnym ciężkim (Apg 2/3/4), z masą ciała 1560 g. Na sali porodowej w resuscytacji zastosowano początkowo Neopuff, masaż pośredni serca, następnie został zaintubowany w 3. min życia i otrzymał surfaktant. Z pępowiny pobrano krew na badania biochemiczne w kierunku infekcji oraz wymaz z ucha. Przewieziony został inkubatorem transportowym na Oddział Intensywnej Terapii Noworodkowej.

Po przyjęciu na oddział noworodka umieszczono w inkubatorze, wentylowano mechanicznie w opcji SIMV. Na podstawie badania przedmiotowego poza cechami wcześniactwa stwierdzono szare zabarwienie powłok skórnych, wybroczyny głównie na tułowiu, twardziny, zaburzenia krążenia obwodowego, tachykardię, obniżone napięcie mięśniowe, małą aktywność, brak jąder w mosznie oraz spodziectwo prąciowe. Z powodu narastania niewydolności oddechowej oraz coraz większego zapotrzebowania na tlen po 12 godz. podano 2. dawkę surfaktantu. W badaniu RTG klatki piersiowej stwierdzono NRDS II stopnia. W badaniach dodatkowych stwierdzono podwyższone parametry stanu zapalnego (tab. 1). Pobrano posiew krwi, wykonano punkcję lędźwiową i włączono antybiotykoterapię skojarzoną (ampicylina + gentamycyna), przetoczono osocze świeżo mrożone. Wynik badania ogólnego płynu mózgowo-rdzeniowego (PMR) uznano za prawidłowy (tab. 2). W posiewie krwi oraz wymazie $\mathrm{z}$ ucha pobranych na sali porodowej wyhodowano L. monocytogenes. Z uwagi na brak poprawy stanu ogólnego dziecka, pomimo stopniowej normalizacji parametrów zapalnych (tab. 1), w 8. dobie życia ponownie wykonano punkcję lędźwiową. Rozpoznano ropne zapalenie

TABELA 1. Wynik badań biochemicznych

\begin{tabular}{lcccc}
\multicolumn{1}{c}{ Doba życia } & 1. d.ż & 3. d.ż. & 6. d. $\dot{z}$. & 13. d.ż. \\
\hline CRP $(\mathrm{mg} / \mathrm{L})$ & 54,7 & 78,70 & 12,4 & 2,80 \\
\hline $\mathrm{IL}-6(\mathrm{pg} / \mathrm{mL})$ & 47257 & 36,3 & 13,7 & 4,9 \\
\hline CPK $(\mathrm{U} / \mathrm{L})$ & 488 & 2049 & - & - \\
\hline PCT $(\mathrm{ng} / \mathrm{mL})$ & - & 30,42 & 1,55 & 0,13 \\
\hline WBC (G/L) & 2,96 & 51,28 & 52,90 & 16,45 \\
\hline PLT (G/L) & 235 & 77 & 269 & 189 \\
\hline WL & 0,61 & 0,23 & 0,44 & 0,25 \\
\hline
\end{tabular}

CRP - białko C-reaktywne; IL-6 - interleukina 6; CPK - kinaza keratynowa; PCT - prokalcytonina; WBC - leukocyty; PLT - płytki krwi; WL - wskaźnik leukocytarny

TABELA 2. Wynik badania ogólnego płynu mózgowo-rdzeniowego

\begin{tabular}{|c|c|c|c|c|c|}
\hline Doba życia & 1. d.ż. & 8. d.ż. & 12. d.ż. & 17. d.ż. & 21. d.ż. \\
\hline Barwa & $\begin{array}{l}\text { lekko } \\
\text { ksantochromiczna }\end{array}$ & ksantochromiczna & ksantochromiczna & ksantochromiczna & wodojasna \\
\hline Przejrzystość & zupetna & mętny & mętny & lekko mętny & lekko mętny \\
\hline Cytoza (/uL) & $\begin{array}{l}\mathrm{G}-4, \mathrm{~L}-\mathrm{brak} \\
\mathrm{Er}-70\end{array}$ & $\begin{array}{l}G-547, L-502 \\
E r-90000\end{array}$ & $\begin{array}{l}\mathrm{G}-807, \mathrm{~L}-807 \\
\mathrm{Er}-86000\end{array}$ & $\begin{array}{l}G-97, L-5, \\
E r-3090\end{array}$ & $\begin{array}{l}G-4, L-9, \\
E r-6720\end{array}$ \\
\hline Białko (mg/dL) & 82,7 & 132,7 & 141,1 & 108,4 & 93,7 \\
\hline Glukoza (mg/dL) & 35 & 22 & 8 & 12 & 27 \\
\hline Chlorki (mmol/L) & 113,0 & 124,0 & 123,0 & 122,0 & ujemny \\
\hline Odczyn Nonne-Apelta & ujemny & ujemny & ujemny & ujemny & wątpliwy \\
\hline Odczyn Pandy'ego & słabo dodatni & wybitnie dodatni & wybitnie dodatni & dodatni & \\
\hline
\end{tabular}

G - granulocyty; L - limfocyty; Er - erytrocyty 
opon mózgowo-rdzeniowych (tab. 2). Wynik posiewu PMR był ujemny. Celem weryfikacji flory patogennej diagnostykę rozszerzono o badanie PCR PMR, również otrzymując wynik ujemny. Ostatecznie w leczeniu poza ampicyliną zastosowano meronem, uzyskując stopniową normalizację parametrów płynu mózgowo-rdzeniowego i poprawę kliniczną pacjenta. Leczenie zapalenia opon mózgowo-rdzeniowych w całości trwało 24 doby (ampicylina, ampicylina + meronem). Diagnostykę poszerzono o badania obrazowe. W oparciu o ocenę ultrasonograficzną mózgowia rozpoznano krwawienie dokomorowe II stopnia z następowym poszerzeniem rogów czołowych komór bocznych, obecność skrzepu w komorze III oraz ogniska leukomalacji przykomorowo (ryc. 1 i 2).

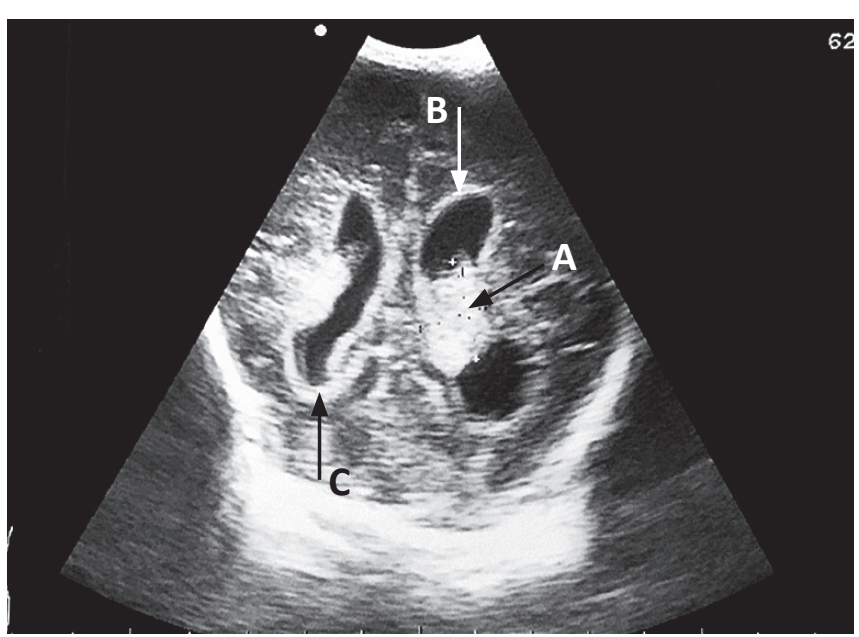

RYCINA 1. Krwawienie do komór (A), poszerzenie rogów czołowych komór bocznych (B), świecenie wyściółki komór (C)

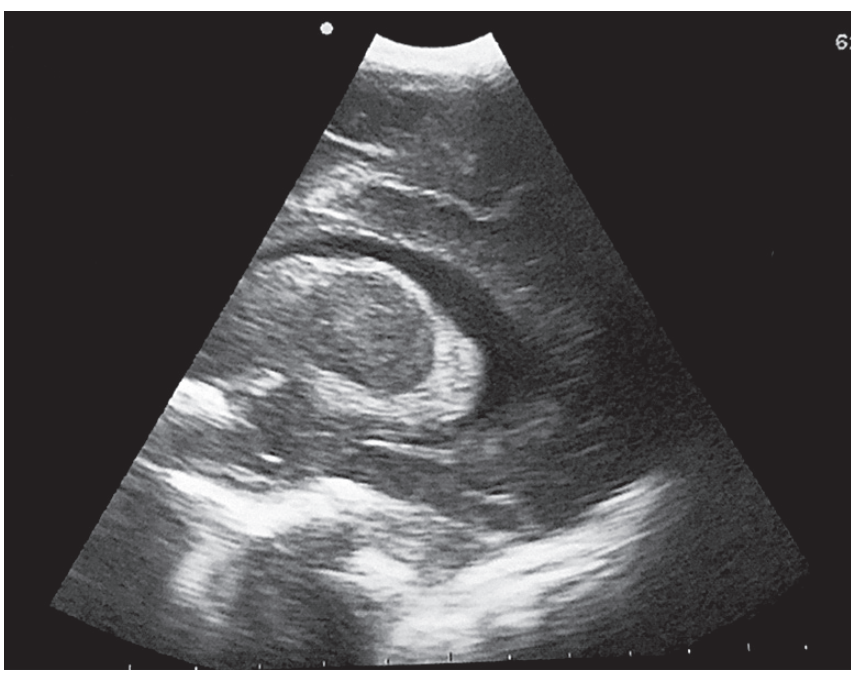

RYCINA 2. Krwawienie do komory bocznej

W pierwszych dniach życia noworodek był konsultowany kardiologicznie z powodu utrzymującego się szmeru nad sercem. Rozpoznano hemodynamicznie istotny przeciek przez przewód tętniczy (hsPDA). Podjęto próbę leczenia farmakologicznego (Pedea), uzyskując pozytywny efekt po 3 dobach. Inwazyjną wentylację prowadzono do 6. d.ż., następnie wspomagano oddychanie n-CPAP-em przez 3 kolejne dni, a tlenoterapię bierną stosowano do 37. d.ż. W trakcie hospitalizacji pacjent był konsultowany przez okulistę - siatkówka w granicy fizjologii wcześniaczej. Wymagał jeden raz transfuzji uzupełniającej krwi.

Dziecko zostało wypisane do domu w stanie dobrym w 46. d.ż. (36/37 Hbd). Znajduje się pod stałą opieką Poradni Patologii Noworodka, a ponadto objęte jest kompleksową opieką - kardiologa, neurologa, chirurga i okulisty oraz intensywnie rehabilitowane. W kontrolnych badaniach ultrasonograficznych mózgowia utrzymuje się poszerzenie rogów czołowych komór bocznych, rogi potyliczne są nieposzerzone, natomiast początkowo widoczne ognisko leukomalacji przykomorowej obecnie jest niewidoczne.

\section{PODSUMOWANIE}

Listerioza chociaż jest dość rzadko występującą chorobą u noworodków, ma zazwyczaj bardzo ciężki przebieg. Pierwsze objawy nie odbiegają od objawów zakażenia uogólnionego florą typową dla tego okresu. W przypadku porodu przedwczesnego czy też obecności zielonych wód płodowych warto pogłębić wywiad od matki i pobrać materiał na badania mikrobiologiczne już na sali porodowej. U ciężarnych listerioza może przebiegać pod postacią gorączki lub bezobjawowo. Do zakażenia najczęściej dochodzi w III trymestrze ciąży, w okresie najniższej odporności komórkowej. Objawy mogą być bardzo niespecyficzne, imitujące zakażenie wirusowe, jak bóle głowy, pleców, mięśniowe czy stawów, ogólne złe samopoczucie, gorączka lub dreszcze [2]. 0 ile u matek choroba ta ma zazwyczaj przebieg samoograniczający się, o tyle u noworodka może być przyczyną zgonu. Zakażenie L. monocytogenes najczęściej przebiega pod postacią uogólnionego zakażenia, a objawy nie różnią się od objawów bakteriemii wywołanej przez inne bakterie [3]. Szczególną cechą tego drobnoustroju jest wyraźny tropizm do komórek układu nerwowego. Wczesna antybiotykoterapia zapobiega odległym powikłaniom neurologicznym (ropień mózgu, wodogłowie, trwałe uszkodzenia neurologiczne). W leczeniu zakażenia o tej etiologii należy pamiętać, że listeria jest niewrażliwa na cefalosporyny, a antybiotykiem z wyboru jest ampicylina. Podstawą zapobiegania zakażeniu wrodzonemu listerią jest przede wszystkim właściwa edukacja kobiet ciężarnych dotycząca sposobu przechowywania żywności, zalecenia dietetyczne zakazujące spożywania niegotowanego mleka, miękkich serów czy surowych produktów mięsnych i warzywnych bez uprzedniego odpowiedniego ich przygotowania. Pomimo że jest to choroba rzadka, z uwagi na ciężkość objawów i potencjalnie wysokie ryzyko zgonu celowym wydaje się rozważenie ampicyliny w empirycznej terapii zakażeń uogólnionych przy braku poprawy po standardowo stosowanym leczeniu. Zarówno w Polsce, jak i w całej Unii Europejskiej zakażenia uogólnione pod postacią bakteriemii, zapalenia opon mózgowo-rdzeniowych, ogniskowej listeriozy, listeriozy noworodków i kobiet ciężarnych podlegają obowiązkowi zgłaszania do Sanepidu. 


\section{PIŚMIENNICTWO}

1. Sikora A, Sikora AG, Adamczyk M. Listerioza u noworodka - opis przypadku. Forum Zakażeń 2015;6(5):353-7. doi: 10.15374/FZ2015048.

2. Lekan M., Pawłowska B. Listerioza wrodzona i jej konsekwencje - prezentacja przypadku klinicznego. Curr Probl Psychiatry 2011;12(4):479-82.

3. Kołakowska A, Madajczak G. Listeria monocytogenes w zakażeniach ludzi. Przegl Epidemiol 2011;65(1):57-62.

4. Galińska E, Knap JP, Stroczyńska-Sikorska M. Listerioza - mało znana, niebezpieczna choroba zakaźna. Med Ogólna 2010;16(45)4:516-26.

5. Gałęziowska M, Kondała-Chojnacka A. Listerioza wrodzona - opis przypadku. Post Neonatol 2013;1(19):51-3.

6. Bander D. Listerioza. In: Kordek A, Torbe A, editors. Zakażenia w ciąży i okołoporodowe. Postępowanie z matką i noworodkiem. Warszawa: Medical Tribune; 2017. p. 127-34
7. Charlier C, Perrodeau E, Leclercq A, Cazenave B, Pilmis B, Henry B, et al. Clinical features and prognostic factors of listeriosis: the MONALISA national prospective cohort study. Lancet Infect Dis 2017;17(5):510-9. doi: 10.1016/S1473-3099(16)30521-7.

8. Villa G, Diana MC, Solari N, Bandettini R, Sorrentino S, Loy A, et al. Listeria meningitis in an immunocompetent child. Pediatr Emerg Care 2017;33(8):579-81. doi: 10.1097/PEC.0000000000000687.

9. Madjunkov M, Chaudhry S, Ito S. Listeriosis during pregnancy. Arch Gynecol Obstet 2017;296(2):143-52. doi: 10.1007/s00404-0174401-1.

10. Barikbin P, Sallmon H, Hüseman D, Sarioglu N, Weichert A, von Weizsäcker K, et al. Clinical, laboratory, and placental findings in perinatal listeriosis. Fetal Pediatric Pathol 2016;35(5):307-14. doi: 10.1080/15513815.2016.1179822. 